\title{
Effect of Moringa oleifera Leaf Meal on Feed Intake and Growth Performance of Murrah Buffalo Calves
}

\author{
Bhavna Aharwal*, Biswajit Roy, G.P. Lakhani, R.P.S. Baghel, \\ Kiran Pal Singh Saini and Aayush Yadav
}
Department of Livestock Production and Management, College of Veterinary Science and Animal Husbandry, NDVSU, Jabalpur, M.P., India

*Corresponding author

\section{A B S T R A C T}

\section{Keywords \\ Moringa oleifera, Calf starter, Concentrate mixture \\ Article Info \\ Accepted: \\ 12 August 2018 Available Online: \\ 10 September 2018}

The study was designed to assess the effect of Moringa oleifera leaf meal on feed intake and growth performance of murrah buffalo calves. A total of 12 Murrah buffalo calves with similar body weight of either sex at the age of $5^{\text {th }}$ day was selected and randomly distributed in two different groups (Control and M10) with six calves in each group. Control group reared on calf starter along with milk. Whereas along with milk calf starter was replaced by Moringa oleifera leaf meal @ of 10\% for M10 group. Result revealed that the body weight changes, average daily gain, dry matter intake, average daily dry matter intake (\% BW), protein efficiency was significantly varied among the group. It can be concluded that Moringa leaf meal can replace upto 10 per cent of calf starter and concentrate mixture to attend better body weight gain of Murrah buffalo calf rearing.

\section{Introduction}

Calves are the future of a dairy farm. Calves at their pre-ruminant stage, solely depend on milk which is indispensible for nourishment and gradually adapt to solid feed (Moran, 2011). Moringa oleifera of Monogeneric family moringaceae is commonly referred to as 'drumstick tree' and is locally known as "Saijhan" or "Mungaa" describing the shape of its pod or 'horseradish tree'. There are 13 species, out of which Moringa oleifera is very common and easily available in India. It is nutritious, fast-growing and drought tolerant. It has been dubbed as the "miracle tree" or "tree of life" in popular media (Anwar et al., 2005). It is a multipurpose tree that is cultivated both for human food and animal feed in India (Anjorin et al., 2010). Leaves are usually considered as source of protein. However, the protein content range from 15\% to $30 \%$ (on DM basis) as it depends on the stage of maturity and on the fodder's respective proportions of leaflets, petioles and stems. Moringa leaves have a very high biological value and considerable potential for adoption as feed for ruminant fodder resource (Pradhan, 2016). It is rich in protein, amino acids, fatty acids, minerals, vitamins, calcium, potassium, various phenolic and 
oxycaroteniod which are the basic building blocks of animal body (Deshmukh, 2014). These nutrients are used for osmotic adjustment, activation of enzymes, growth hormones and other organic molecules that enhance growth, function and maintenance of life process (Anjorin et al., 2010). It may contain certain amounts of anti-nutritional factors like tannins, phenol and saponins (Oliveira et al., 1999). Looking to the nutritional potentiality and the availability of Moringa oleifera can be explored (Sarwatt et al., 2004). Moringa leaves are inexpensive, easily available and provides unconventional source of nutrients. Moringa oleifera plants are readily available in Madhya Pradesh. Despite all these benefits, no reports are traced out about the use of Moringa leaf as a feeds for Murrah buffalo calves.

\section{Materials and Methods}

Proposed work was conducted at Livestock farm, Adhartal, College of Veterinary Science \& A.H., Nanaji Deshmukh Veterinary Science University, Jabalpur (M.P.). There was 12 Murrah buffalo calves of either sex from 5 days of age selected for experiment. All the calves was permanently separated from dam just after birth. Colostrum and milk was offered as per standard protocol. Milk offered to the calves upto 90 days of age. A total of 24 murrah buffalo calves was selected for the study and grouped as follows (Table 1 and 2).

\section{Preparation of Moringa leaf meal (MLM)}

The branches with leaves and soft twigs was used for the prepration of Moringa leaves was collected from Moringa by cutting every 45 days. The harvested leaves soft twigs was sundried for 2-3 days before partially dried leaves was removed by threshing and then sun-dried again for approximately $48 \mathrm{hrs}$ on black plastic sheets. The dried leaves was finely ground in a hammer mill, packed in sacks and stored in a well-ventilated storeroom.

\section{Proximate analysis of feed and fodder}

Green grasses, wheat straw, calf starter and concentrate mixture was analyzed to know the dry matter, crude protein, ether extract, crude fiber, nitrogen free extract and total ash content as per the methods described in the manual of Association of Official Analytical Chemist (AOAC, 2012).

\section{Composition of buffalo milk}

During the study period, chemical composition (\%) of buffalo milk was evaluated and presented in table 3 . The milk composition like fat, protein, lactose, minerals, total solid, solid not fat was 7.05, $3.84,4.82,0.87,16.58$ and 9.53 , respectively.

\section{Composition of feed, fodders and dry Moringa leaves}

The proximate composition of calf starter, concentrate mixture, wheat straw, green fodders (berseem, oat and maize) and dry Moringa leaves are presented in table 4. Dry matter $(\%)$ content of calf starter, concentrate mixture, wheat straw, berseem, oat, maize and dry Moringa leaves was 92.21, 92.79, 92.01, 16.23, 20.52, 24.51 and 90.86, respectively. Crude protein $(\%)$ content of calf starter, concentrate mixture, wheat straw, berseem, oat, maize and dry Moringa leaves was 22.12, $20.11,2.92,18.25,14.23,13.21$ and 25.31, respectively. Ether extract (\%) content of calf starter, concentrate mixture, wheat straw, berseem, oat, maize and dry Moringa leaves was 4.79, 4.68, 2.12, 6.11, 5.11, 5.01 and 6.21, respectively. Crude fiber (\%) content of calf starter, concentrate mixture, wheat straw, berseem, oat, maize and dry Moringa leaves was 8.06, 8.75, 38.22, 22.96, 23.23, 26.64 and 14.95 , respectively. Nitrogen free extract $(\%)$ 
content of calf starter, concentrate mixture, wheat straw, berseem, oat, maize and dry Moringa leaves was 57.22, 58.35, 37.83, $42.44,47.32,45.03$ and 44.77, respectively. Total ash (\%) content of calf starter, concentrate mixture, wheat straw, berseem, oat, maize and dry Moringa leaves was 7.81, 8.11, 18.91, 10.24, 10.11, 10.11 and 8.76, respectively.

Proximate composition of calf starter replaced by various level of Moringa leaf meal offered to the experimental calves (upto 3 months age)

The proximate composition (\%) of calf starter offered to the calves i.e., control and M10 group are presented in table 5. Dry matter (\%) content of calf starter in different group was 92.21and 92.12 respectively. Crude protein (\%) content in control, and M10 group was 22.12 and 22.44 respectively. Ether extract (\%) content in control and M10 group was 4.79 and 4.93 respectively. Crude fiber (\%) content in control and M10 group was 8.06 and 8.75 respectively. Nitrogen free extract (\%) content in control and M10 group was 57.22 and 56.60 respectively. Total ash (\%) content in control and M10 was 7.81 and 7.91 respectively.

Proximate composition of concentrate mixture replaced by $\mathbf{1 0}$ per cent of Moringa leaf meal offered to the experimental calves (above 3 months of age)

The proximate composition (\%) of concentrate mixture offered to the Murrah buffalo calves in different group are presented in table 6. Dry matter $(\%)$ content of concentrate mixture was 92.79 and 92.60 in control and M10 group, respectively. Crude protein (\%) was 20.11 and 20.63 in control and M10 group, respectively. Ether extract (\%) was 4.68 and 4.83 in control, and M10 group, respectively. Crude fiber (\%) was 8.75 and 9.37 in control and M10 group, respectively. Nitrogen free extract (\%) was 58.35 and 56.99 in control and M10 group, respectively. Total ashes (\%) was 8.11 and 8.18 in control and M10 group, respectively.

\section{Results and Discussion}

\section{Body weight}

Fortnightly average body weight changes are presented in table 7 . Fortnightly average body weight (kg/animal) of the calves at the start of experiment was $32.78 \pm 1.06$ and $32.43 \pm 1.00$ in control and M10 group, respectively. At $6^{\text {th }}$ fortnight body weight (kg/animal) of the calves was $56.86 \pm 1.12$ and $58.34 \pm 1.15$ in control, M10 group, respectively at the end of the pre-weaning period.

During post-weaning period at $7^{\text {th }}$ fortnight. The average body weight was $60.90 \pm 1.15$ and $63.73 \pm 1.44$ in control and M10 group, respectively. At $12^{\text {th }}$ fortnight average body weight (kg/animal) of the calves was $82.83 \pm 1.38$ and $90.21 \pm 1.87$ in control and M10 group, respectively. On $9^{\text {th }}$ fortnight onwards the significant differences $(p<0.05)$ of average body weight was observed. The trend continued upto the end of experiment. Final average body weight of the calves in different group indicated that there was 8.30 per cent increases of body weight over control group.

\section{Average daily body weight gain}

Fortnightly average daily gain (ADG) are presented in table 8. During pre-weaning period at $1^{\text {st }}$ fortnight the ADG (kg/calf) was $0.509 \pm 0.006$ and $0.353 \pm 0.021$ in control and M10 group, respectively. At the end of preweaning period i.e., at $6^{\text {th }}$ fortnight the ADG (kg/calf) of the calves was $0.300 \pm 0.001$ and $0.311 \pm 0.025$ in control and M10 group, respectively. The overall ADG at pre-weaning period was $0.352 \pm 0.009$ and $0.374 \pm 0.010$ in 
control and M10 group, respectively. There was no significant differences $(p<0.05)$ in ADG among the group during pre-weaning period in all fortnights except $6^{\text {th }}$ fortnight. During post-weaning period at $7^{\text {th }}$ fortnight the ADG (kg/calf) was $0.299 \pm 0.004$ and $0.364 \pm 0.020$ in the control and M10 group, respectively. At $12^{\text {th }}$ Fortnight ADG (kg/calf) gain of the calves at post-weaning period was $0.442 \pm 0.026$ and $0.380 \pm 0.048$ in control and M10 group, respectively. The overall ADG during post-weaning period was $0.312 \pm 0.005$ and $0.380 \pm 0.012$ in control and M10 group, respectively. Statistical analysis indicated that there was significant differences $(\mathrm{p}<0.05)$ in ADG among the group during post-weaning period in all fortnight except $11^{\text {th }}$ fortnight.

\section{Total dry matter intake (TDMI)}

Fortnightly average total dry matter intake (TDMI) is presented in table 9. During preweaning period at $1^{\text {st }}$ fortnight the average TDMI (kg/calf/day) was $0.54 \pm 0.02$ and $0.54 \pm 0.02$ in control and M10 group, respectively. At the end of pre-weaning period i.e., at $6^{\text {th }}$ fortnight the average TDMI (kg/calf/day) was $0.96 \pm 0.01$ and $0.97 \pm 0.01$ in control and M10 group, respectively. The overall average TDMI total dry matter intake was $0.768 \pm 0.018$ and $0757 \pm 0.019$ in control and M10 group, respectively. There was no significant differences $(p<0.05)$ in ADG among the group during different fortnights except $6^{\text {th }}$ fortnight.

During post-weaning period at $7^{\text {th }}$ fortnight the average total dry matter intake TDMI (kg/calf/day) was $0.96 \pm 0.01$ and $0.84 \pm 0.01$ in control and M10 group, respectively. At the end of post-weaning period i.e., at $12^{\text {th }}$ fortnight the average TDMI ( $\mathrm{kg} / \mathrm{calf} /$ day) was $2.12 \pm 0.01$ and $2.30 \pm 0.01$ in control and M10 group, respectively. The overall average TDMI (kg/calf/day) at the end of the postweaning period was $1.585 \pm 0.005$ and
$1.586 \pm 0.062$ in control and M10 group, respectively. On $7^{\text {th }}$ fortnight onwards the significance differences $(p<0.05)$ of average TDMI (kg/calf/day) was observed except $9^{\text {th }}$ and $10^{\text {th }}$ fortnight. The trend continued upto the end of experiment.

\section{Total dry matter intake (\% BW)}

Fortnightly average total dry matter intake TDMI (\%BW) are presented in table 10. During pre-weaning period at $1^{\text {st }}$ fortnight the average TDMI was $1.66 \pm 0.01$ and $1.67 \pm 0.01$ in control and M10 group, respectively. At the end of pre-weaning period i.e., at $6^{\text {th }}$ fortnight the average TDMI (\%BW) was $1.68 \pm 0.02$ and $1.67 \pm 0.03$ in control and M10 group, respectively. The overall average TDMI (\%BW) was $1.680 \pm 0.012$ and $1.652 \pm 0.014$ in control M10 group, respectively. There was no significant difference $(\mathrm{p}<0.05)$ of average total dry matter intake (\%BW) among the group during different fortnights fortnight. During post-weaning period at $7^{\text {th }}$ fortnight the average total dry matter intake TDMI (\%BW) was $1.58 \pm 0.04$ and $1.35 \pm 0.03$ in control M10 group, respectively. At the end of postweaning period i.e., at $12^{\text {th }}$ fortnight the average TDMI (\%BW) was $2.56 \pm 0.06$, and $2.56 \pm 0.06$ in control and M10 group, respectively. The overall average TDMI $(\% \mathrm{BW})$ at the end of the post-weaning period was $2.178 \pm 0.053$ and $2.021 \pm 0.055$ in control and M10 group, respectively. On $7^{\text {th, }} 9^{\text {th }}$ and $10^{\text {th }}$ fortnight was significantly differ $(\mathrm{p}<0.05)$ of average TDMI (\%BW) was observed.

\section{Crude protein intake (CP)}

Fortnightly average crude protein $\mathrm{CP}$ intake (kg/calf) are presented in table 11. During preweaning period at $1^{\text {st }}$ fortnight the average total dry matter intake was $0.126 \pm 0.004$ and $0.125 \pm 0.004$ in control and M10 group, respectively. At the end of pre-weaning period i.e., at $6^{\text {th }}$ fortnight the average $\mathrm{CP}$ intake 
(kg/calf) was $0.180 \pm 0.002$ and $0.185 \pm 0.002$ in control and M10 group, respectively. The overall average $\mathrm{CP}$ intake (kg/calf) was $0.164 \pm 0.003$ and $0.163 \pm 0.003$ in control and M10 group, respectively. There was no significant difference $(\mathrm{p}<0.05)$ of average total $\mathrm{CP}$ intake (kg/calf) among the group during different fortnights fortnight. During postweaning period at $7^{\text {th }}$ fortnight the average CP intake $(\mathrm{kg} / \mathrm{calf})$ was $0.162 \pm 0.002$ and $0.135 \pm 0.011$ in control and M10 group, respectively. At the end of post-weaning period i.e., at $12^{\text {th }}$ fortnight the average $\mathrm{CP}$ intake $(\mathrm{kg} /$ calf $)$ was $0.424 \pm 0.002$, and $0.471 \pm 0.012$ in control and M10 group, respectively. The overall average $\mathrm{CP}$ intake (kg/calf) at the end of the post-weaning period was $0.281 \pm 0.011$ and $0.301 \pm 0.014$ in control and M10 group, respectively. On $7^{\text {th }}$ fortnight onwards the significance difference $(p<0.05)$ of average $\mathrm{CP}$ intake $(\mathrm{kg} / \mathrm{calf})$ was observed except $10^{\text {th }}$ fortnight. The trend continued upto the end of experiment.

\section{Protein efficiency ratio}

Average protein efficiency ratio PER in preweaning period are presented in table 12 was $2.15 \pm 0.08$ and $2.30 \pm 0.08$ in control and M10 group, respectively. Average PER in postweaning stage was $1.25 \pm 0.05$ and $1.59 \pm 0.08$ in control and M10 group, respectively. However the overall average PER was $1.68 \pm 0.06$ and $1.93 \pm 0.06$ in control and M10 group, respectively. Average protein efficiency ratio statistically shows the significant difference $(p<0.05)$ among the group in post-weaning period.

\section{Faecal score}

The faecal score is shown in table 13. In preweaning period was $2.27 \pm 0.38$ and $1.88 \pm 0.11$ in control and M10 group, respectively and in post-weaning period was 3.67 \pm 0.01 and $2.55 \pm 0.29$ in control and M10 group, respectively. Statistical analysis shows that there were no significant differences in preweaning and post-weaning period.

Buffalo is the backbone of the dairy industry in India. Rearing of buffalo calves has immense importance to maintain replacement stock. Increasing numbers of commercial dairy farms in the urban, peri-urban, metros and big cities is the common phenomenon during the last two decades. Buffalo calves of very young age are sold and subsequently slaughtered indiscriminately. It causes genetic drain of the elite buffalo breeds. Underfed buffalo calves result in poor growth rate, prone to disease and late maturity. Therefore, special emphasis needs to be given the calves using alternate, cheap and readily available feed resources (Farooq and Qudoos, 1991). Calf starter, first solid feed, provides a convenient way to feed pre-ruminant calves for the development of its rumen. Any feed ingredient or feed resources which can economically replace the conventional feed resources along with boost growth and health status of the calves is a real game changer in calf rearing (Iqbal and Ahmad, 2002). Over the years, Moringa leaves are gaining popularity as animal feed. The dried form of leaves successfully added to the diet of various categories of animals (Ahmad et al., 2017 and Ali et al., 2018).

\section{Composition of buffalo milk}

During the experimental period, chemical composition (\%) of buffalo milk evaluated and is presented in table 3 . The milk composition (\%) like fat, protein, lactose, minerals, total solid, solid not fat were 7.05, 3.84, 4.82, 0.87, 16.58 and 9.53, respectively. Milk consumed by calves is within a normal range of the milk composition (\%) i.e., fat, protein, lactose and total solid and SNF were 7.11, 3.82, 4.81, 16.56 and 9.45, respectively (Shakya, 2017). 
Table.1 Feeding schedule of buffalo calves

\begin{tabular}{|c|c|c|c|c|}
\hline Age (days) & Colostrum (kg) & Milk (kg) & Calf starter (g) & Green fodder \\
\hline $0-5$ & $1 / 10^{\text {th }}$ of body weight & - & - & - \\
\hline $6-30$ & - & $\begin{array}{c}1 / 10^{\text {th }} \text { of body } \\
\text { weight }\end{array}$ & - & - \\
\hline $31-60$ & - & $\begin{array}{c}1 / 15^{\text {th }} \text { of body } \\
\text { weight }\end{array}$ & 125 & Adlib \\
\hline 61-90 & - & $\begin{array}{c}1 / 25^{\text {th }} \text { of body } \\
\text { weight }\end{array}$ & 250 & Adlib \\
\hline $91-150$ & - & - & $500-1000$ & Adlib \\
\hline 151-180 & - & - & $1000-1500$ & Adlib \\
\hline
\end{tabular}

Table.2 Grouping of animals and their diet

\begin{tabular}{|l|l|l|l|}
\hline S. No & Group & No. of calves & Treatment \\
\hline 1 & Control & 6 & Calf starter \\
\hline 2 & M10 & 6 & $\begin{array}{l}10 \% \text { calf starter/concentrate } \\
\text { mixture replaced by dry Moringa } \\
\text { leaves }\end{array}$ \\
\hline
\end{tabular}

\section{Table.3 Composition of buffalo milk offered to the experimental animals}

\begin{tabular}{|l|c|}
\hline Parameters & Value (\%) \\
\hline Fat & 7.05 \\
\hline Protein & 3.84 \\
\hline Lactose & 4.82 \\
\hline Minerals & 0.87 \\
\hline Total solid & 16.58 \\
\hline Solid not fat & 9.53 \\
\hline
\end{tabular}

Table.4 Proximate composition (\%) of feed, fodders and Moringa leaves

\begin{tabular}{|c|c|c|c|c|c|c|c|}
\hline \multicolumn{2}{|c|}{ Parameters (\%) } & $\begin{array}{l}\text { Dry } \\
\text { matter }\end{array}$ & $\begin{array}{l}\text { Crude } \\
\text { protein }\end{array}$ & $\begin{array}{l}\text { Ether } \\
\text { extract }\end{array}$ & $\begin{array}{l}\text { Crude } \\
\text { fibre }\end{array}$ & $\begin{array}{l}\text { Nitrogen } \\
\text { free extract }\end{array}$ & $\begin{array}{l}\text { Total } \\
\text { ash }\end{array}$ \\
\hline \multicolumn{2}{|c|}{ Calf starter } & 92.21 & 22.12 & 4.79 & 8.06 & 57.22 & 7.81 \\
\hline \multicolumn{2}{|c|}{ Concentrate mixture } & 92.79 & 20.11 & 4.68 & 8.75 & 58.35 & 8.11 \\
\hline \multicolumn{2}{|c|}{ Wheat straw } & 92.01 & 2.92 & 2.12 & 38.22 & 37.83 & 18.91 \\
\hline \multirow{3}{*}{$\begin{array}{l}\text { Green } \\
\text { fodders }\end{array}$} & Berseem & 16.23 & 18.25 & 6.11 & 22.96 & 42.44 & 10.24 \\
\hline & Oat & 20.52 & 14.23 & 5.11 & 23.23 & 47.32 & 10.11 \\
\hline & Maize & 24.51 & 13.21 & 5.01 & 26.64 & 45.03 & 10.11 \\
\hline \multicolumn{2}{|c|}{ Moringa leaves } & 90.86 & 25.31 & 6.21 & 14.95 & 44.77 & 8.76 \\
\hline
\end{tabular}


Table.5 Proximate composition (\%) of calf starter replaced by various level of Moringa leaf meal, offered to the experimental calves (upto 3 months of age)

\begin{tabular}{|l|c|c|}
\hline Parameters (\%) & Control & M10 \\
\hline Dry matter & 92.21 & 92.12 \\
\hline Crude protein & 22.12 & 22.44 \\
\hline Ether extract & 4.79 & 4.93 \\
\hline Crude fibre & 8.06 & 8.75 \\
\hline Nitrogen free extract & 57.22 & 55.98 \\
\hline Total ash & 7.81 & 7.91 \\
\hline
\end{tabular}

Table.6 Proximate composition (\%) of concentrate mixture offered to the different group

\begin{tabular}{|l|c|c|}
\hline Parameters $(\boldsymbol{\%})$ & Control & M10 \\
\hline Dry matter & 92.79 & 92.60 \\
\hline Crude protein & 20.11 & 20.63 \\
\hline Ether extract & 4.68 & 4.83 \\
\hline Crude fibre & 8.75 & 9.37 \\
\hline Nitrogen free extract & 58.35 & 56.99 \\
\hline Total ash & 8.11 & 8.18 \\
\hline
\end{tabular}

Table.7 Effect of Moringa leaf meal on fortnightly average of body weight (kg/animal) of Murrah buffalo calves

\begin{tabular}{|c|c|c|c|}
\hline Periods & Fortnights & Control & M10 \\
\hline Pre-weaning & 1 & $32.78 \pm 1.06$ & $32.43 \pm 1.00$ \\
\hline 2 & $39.22 \pm 1.03$ & $38.65 \pm 1.09$ \\
\hline 3 & $44.20 \pm 1.02$ & $44.08 \pm 1.10$ \\
\hline Post-weaning & 5 & $48.70 \pm 1.05$ & $48.99 \pm 1.07$ \\
\hline & 6 & $52.78 \pm 1.08$ & $53.28 \pm 0.97$ \\
\hline & 8 & $56.86 \pm 1.12$ & $58.34 \pm 1.15$ \\
\hline & 9 & $60.90 \pm 1.15$ & $62.98 \pm 1.26$ \\
\hline & 10 & $65.63 \pm 1.21$ & $68.91 \pm 1.37$ \\
\hline & 11 & $69.61^{\mathrm{a}} \pm 1.22$ & $73.98^{\mathrm{ab}} \pm 1.40$ \\
\hline Per cent increase of body weight & $73.55^{\mathrm{a}} \pm 1.28$ & $79.36^{\mathrm{b}} \pm 1.53$ \\
\hline over control group & & $78.13^{\mathrm{a}} \pm 1.33$ & $84.86^{\mathrm{b}} \pm 1.70$ \\
\hline
\end{tabular}

Means bearing different superscripts within same row differ significantly $\left({ }^{a b}, p<0.05\right)$ 
Table.8 Effect of Moringa leaf meal on fortnightly average daily body weight gain ( $\mathrm{kg} / \mathrm{calf})$ of Murrah buffalo calves

\begin{tabular}{|l|l|c|c|}
\hline Periods & Fortnights & Control & M10 \\
\hline Pre-weaning & 1 & $0.509 \pm 0.006$ & $0.353 \pm 0.021$ \\
\hline & 2 & $0.435 \pm 0.011$ & $0.442 \pm 0.026$ \\
\hline 3 & $0.334 \pm 0.011$ & $0.487 \pm 0.025$ \\
\hline 4 & $0.322 \pm 0.008$ & $0.425 \pm 0.019$ \\
\hline 5 & $0.290 \pm 0.004$ & $0.371 \pm 0.017$ \\
\hline Post-weaning & 7 & $0.300^{\mathrm{a}} \pm 0.001$ & $0.311^{\mathrm{b}} \pm 0.025$ \\
\hline & Overall & $0.352 \pm 0.009$ & $0.374 \pm 0.010$ \\
\hline & 8 & $0.299^{\mathrm{a}} \pm 0.004$ & $0.364^{\mathrm{a}} \pm 0.020$ \\
\hline & 9 & $0.284^{\mathrm{a}} \pm 0.006$ & $0.440^{\mathrm{b}} \pm 0.016$ \\
\hline 10 & $0.362^{\mathrm{a}} \pm 0.005$ & $0.335^{\mathrm{b}} \pm 0.027$ \\
\hline 11 & $0.260^{\mathrm{a}} \pm 0.004$ & $0.410^{\mathrm{b}} \pm 0.019$ \\
\hline & 12 & $0.296 \pm 0.006$ & $0.375 \pm 0.019$ \\
\hline
\end{tabular}

Means bearing different superscripts within same row differ significantly $\left({ }^{\mathrm{ab}}, \mathrm{p}<0.05\right)$

Table.9 Effect of Moringa leaf meal on fortnightly average of total dry matter intake TDMI (kg/calf/day) of Murrah buffalo calves

\begin{tabular}{|c|c|c|c|}
\hline Periods & Fortnights & Control & M10 \\
\hline Pre-weaning & 1 & $0.54 \pm 0.02$ & $0.54 \pm 0.02$ \\
\hline 2 & $0.70 \pm 0.02$ & $0.69 \pm 0.02$ \\
\hline 3 & $0.69 \pm 0.01$ & $0.66 \pm 0.01$ \\
\hline Post-weaning & 5 & $0.78 \pm 0.01$ & $0.77 \pm 0.01$ \\
\hline & 6 & $0.94 \pm 0.01$ & $0.92 \pm 0.01$ \\
\hline & Overall & $0.96^{\mathrm{a}} \pm 0.01$ & $0.97^{\mathrm{a}} \pm 0.01$ \\
\hline & 7 & $0.76 \pm 0.02$ & $075 \pm 0.02$ \\
\hline & 9 & $0.96^{\mathrm{a}} \pm 0.01$ & $0.84^{\mathrm{bc}} \pm 0.01$ \\
\hline & 10 & $1.12^{\mathrm{a}} \pm 0.01$ & $1.09^{\mathrm{ab}} \pm 0.01$ \\
\hline & 11 & $1.46 \pm 0.01$ & $1.41 \pm 0.01$ \\
\hline & 12 & $1.84 \pm 0.02$ & $1.81 \pm 0.01$ \\
\hline & & $2.02^{\mathrm{a}} \pm 0.01$ & $2.06^{\mathrm{b}} \pm 0.01$ \\
\hline & Overall & $2.12^{\mathrm{a}} \pm 0.01$ & $2.30^{\mathrm{b}} \pm 0.01$ \\
\hline
\end{tabular}

Means bearing different superscripts within same row differ significantly $\left({ }^{\mathrm{abc}}, \mathrm{p}<0.05\right)$ 
Table.10 Effect of Moringa leaf meal on fortnightly average of total dry matter intake (\%BW) of Murrah buffalo calves

\begin{tabular}{|c|c|c|c|}
\hline Periods & Fortnights & Control & M10 \\
\hline \multirow{3}{*}{ Pre-weaning } & 1 & $1.66 \pm 0.01$ & $1.66 \pm 0.01$ \\
\hline & 2 & $1.79 \pm 0.01$ & $1.78 \pm 0.01$ \\
\hline & 3 & $1.56 \pm 0.02$ & $1.49 \pm 0.02$ \\
\hline Post-weaning & 5 & $1.60 \pm 0.01$ & $1.57 \pm 0.02$ \\
\hline & 6 & $1.78 \pm 0.02$ & $1.74 \pm 0.03$ \\
\hline & Overall & $1.68 \pm 0.02$ & $1.67 \pm 0.03$ \\
\hline & 7 & $1.68 \pm 0.02$ & $1.65 \pm 0.02$ \\
\hline & 9 & $1.58^{\mathrm{a}} \pm 0.04$ & $1.35^{\mathrm{b}} \pm 0.03$ \\
\hline & 10 & $1.71 \pm 0.05$ & $1.59 \pm 0.03$ \\
\hline & 11 & $2.11^{\mathrm{a}} \pm 0.05$ & $1.91^{\mathrm{b}} \pm 0.03$ \\
\hline & 12 & $2.52^{\mathrm{a}} \pm 0.06$ & $2.29^{\mathrm{b}} \pm 0.04$ \\
\hline & Overall & $2.59 \pm 0.06$ & $2.43 \pm 0.05$ \\
\hline
\end{tabular}

Means bearing different superscripts within same row differ significantly $\left({ }^{\mathrm{ab}}, \mathrm{p}<0.05\right)$

Table.11 Effect of Moringa leaf meal on fortnightly average crude protein intake (kg/calf) of Murrah buffialo calves

\begin{tabular}{|c|c|c|c|}
\hline Periods & Fortnights & Control & M10 \\
\hline Pre- & 1 & $0.126 \pm 0.004$ & $0.125 \pm 0.004$ \\
\hline weaning & 2 & $0.163 \pm 0.004$ & $0.160 \pm 0.004$ \\
\hline & 3 & $0.156 \pm 0.003$ & $0.149 \pm 0.003$ \\
\hline & 4 & $0.174 \pm 0.003$ & $0.173 \pm 0.002$ \\
\hline Post- & 5 & $0.187 \pm 0.002$ & $0.188 \pm 0.001$ \\
\hline weaning & Overall & $0.180^{\mathrm{a}} \pm 0.002$ & $0.185^{\mathrm{a}} \pm 0.002$ \\
\hline & 7 & $0.164 \pm 0.003$ & $0.163 \pm 0.003$ \\
\hline & 8 & $0.162^{\mathrm{a}} \pm 0.002$ & $0.135^{\mathrm{b}} \pm 0.011$ \\
\hline & 10 & $0.187^{\mathrm{a}} \pm 0.002$ & $0.176^{\mathrm{a}} \pm 0.012$ \\
\hline & 11 & $0.237^{\mathrm{a}} \pm 0.004$ & $0.233^{\mathrm{a}} \pm 0.012$ \\
\hline & 12 & $0.305 \pm 0.004$ & $0.313 \pm 0.012$ \\
\hline
\end{tabular}

Means bearing different superscripts within same row and parameters differ significantly $\left({ }^{\mathrm{ab}}, \mathrm{P}<0.05\right)$ 
Table.12 Effect of Moringa leaf meal on protein efficiency ratio of Murrah buffalo calves

\begin{tabular}{|l|c|c|}
\hline \multicolumn{1}{|c|}{ Period } & Control & M10 \\
\hline Pre-weaning & $2.15^{\mathrm{p}} \pm 0.08$ & $2.30^{\mathrm{p}} \pm 0.08$ \\
\hline Post-weaning & $1.25^{\mathrm{aq}} \pm 0.05$ & $1.59^{\mathrm{bq}} \pm 0.08$ \\
\hline Overall & $1.68^{\mathrm{a}} \pm 0.06$ & $1.93^{\mathrm{b}} \pm 0.06$ \\
\hline
\end{tabular}

Means bearing different superscripts within same row $\left({ }^{\mathrm{ab}}\right)$ and same Colum $\left({ }^{\mathrm{pq}}\right)$ between the periods differ significantly $(\mathrm{p}<0.05)$

Table.13 Effect of Moringa leaf meal on average faecal score of Murrah buffalo calves

\begin{tabular}{|l|c|c|}
\hline Periods & Control & M10 \\
\hline Pre-weaning & $2.27 \pm 0.38$ & $1.88 \pm 0.11$ \\
\hline Post-weaning & $3.67 \pm 0.01$ & $2.55 \pm 0.29$ \\
\hline
\end{tabular}

\section{Composition of Moringa oleifera}

Moringa leaves have a very high biological value and considerable potential for adoption as feed for ruminant fodder resource (Pradhan, 2016). It is rich in protein, amino acids, fatty acids, minerals, vitamins, calcium, potassium, various phenolic and oxycaroteniod are the basic building blocks of animal body (Deshmukh, 2014). These nutrients are used for osmotic adjustment, activation of enzymes, growth hormones and other organic molecules that enhance growth, function and maintenance of life process (Ramachandra et al., 1980 and Sarwatt et al., 2004). Moringa leaves are inexpensive easily available and unconventional source of energy.

\section{Composition of calf starter, concentrate mixture and fodder}

In the present study, various ingredients like yellow maize, GNC, fish meal, rice polish, wheat bran, arhar chuni, mineral mixture, common salt and vitamins were used for the preparation of calf starter and concentrate mixture. Calf starter and concentrate mixture was formulated to have $22 \%$ and $20 \%$ crude protein. Green fodder includes berseem, oat and maize were offered to the experimental calves. During the experiment, calf starter and concentrate mixture was analysis and revealed that the proximate values were within the desirable range.

\section{Effect of Moringa leaves on growth performance}

Data of feed intake indicated that DMI was significantly $(p<0.05)$ higher in DMOL supplemented rations 10\% in M10 group than control group. Total body weight gain of buffalo calves fed 10 per cent DMOL supplemented rations were significantly $(\mathrm{p}<0.05)$ higher than control group. It was noticeable that M10 group produced the higher weaning weight. The overall (ADG) was higher in M10. This improvement of ADG in the Moringa fed group might be due to better digestibility of all nutrients (Ahmad et al., 2017). Other studies also indicated that Moringa leaf meal act as natural growth promoter (El-Badawi et al., 2014), which might be a strong reason for better ADG in the Moringa supplemented group.

\section{Feed intake and dry matter intake}

Milk is an excellent source of all kind of nutrients for the young one. Newly born calves have limited energy reserves; therefore, provision of adequate quantities of milk for growth and to maintain the health 
status (Hegazi et al., 2005). In the present study, buffalo calves are separated permanently from the dam. Besides milk, the calves were offered calf starter from $2^{\text {nd }}$ week onwards. Calf starter was prepared in the farm according the formula described in the materials and method section. Beside this good quality green fodders were also offered to the calves (Shakya et al., 2017).

Unlike liquid feeds, solid feeds are directed to rumen for digestion instead of abomasum. During the first few weeks, calf starter intake remain low, due to ample milk intake depresses calf starter intake. Consumption of solid feed is of paramount importance in successful transition from simple stomach to a ruminant (Mahmoud, 2013). New born calves have adequate amount of bacterial population even at early days of their life but the development has been found to be affected by the dry feed consumption (Anderson et al., 1987). Therefore, access to calf starter feed as early as possible encourages starter intake and consequently early rumen development.

In the present study the calves started taking calf starter from $2^{\text {nd }}$ week of age. Gradual increased of calf starter intake upto weaning age indicates the appetite towards the calf starter. After 90 days of age calf starter was replaced by concentrate mixture. The increase of concentrate intake continues upto 6 months of age i.e., at the end of experimental period.

As the age of calf progresses, the milk supplied to the calves (in proportion of their diet) is reduced. Calves fed limited amount of milk consumed double amount of starter as compared to those fed ad libitum milk during the pre-weaning period. Adding calf starter to the diet of the young calf provides the opportunity for rumen development and growth. The grain is fermented in the tiny rumen and produces volatile fatty acids for rumen growth, which leads to a need for water and starter grain, promotes rumen development.

In the present study, significantly increased dry matter intake was reported in the M10 group in comparison to the control group. This is contributed to higher body weight gain in the M10 group during the study. However, the increased nutrient intake in the M10 group were due to the good palatability of Moringa leaf meal.

Efficiency of feed utilization determines how efficiently feed is utilized for the growth of the calves (McDonald et al., 1995). The total DMI was higher in M10 this may be due to the better palatability and these results in superior growth rate. The facts were supported by the finding of the other researcher (Abd El-Aal, 2000). The optimum amount of feed consumed each day, greater will be the opportunity for increasing daily growth. An increase in growth obtained by higher feed intake is usually associated with increase in overall efficiency of the production. Since, maintenance costs are decreased proportionately as growth rises in a certain period (Saleh et al., 2006).

\section{Body weight (BW) changes and average daily body weight gain}

Growth in young calves before weaning mainly occurs in the skeleton and muscle systems. Tissue growth is largely a function of protein deposition in bone and muscle, with corresponding mineralization of the protein matrix in bone. Rates of growth expressed as the percentage increase of body size/weight (Kertz et al., 1998). Body weight at early age also has an important bearing on the life time performance including growth, production and reproduction. Body weights are commonly used for monitoring nutritional status and growth of animals (Chimonyo et al., 2000). 
In the present study body weight changes were slow in the pre-weaning periods in both the group. Average daily gain was highest in M10 group in comparison to control group in pre-weaning period, whereas in post-weaning period average daily gain was higher in M10 group. The results of the present study suggested that feeding buffalo calves plus DMOL, at the levels of $10 \%$ could play as natural growth promoter. The improvement in body weight gain may be attributed to the rich content of nutrients in DMOL and antimicrobial properties of Moringa oleifera leaf meal (Fahey et al., 2001).

\section{Faecal score}

Diarrhoea or scours is one the most common problem reported in calves upto 3 months old (Gakuya et al., 2014). Diarrhoea results in severe dehydration and, in some cases, pathogens that infect the digestive tract invade the bloodstream, causing bacteraemia and sepsis. Buffalo calves are more susceptible to diseases. In severe cases death may occur. In the present study, faecal score, scouring score and days scoured were similar across the group. Calf health was maintained even upto 15 per cent replacement of Moringa leaves in calf starter and concentrate mixture.

In the present study, average daily gain and overall feed intake were maintained across the group. Thus, maintained average daily gain and feed intake along with unaffected fecal score suggest that such known and unknown anti-nutritive factors usually found in Moringa leaves may have been mostly separated or inactivated during the drying of leaves.

High incidence of diarrhoea is usually related with the sanitary, managemental conditions and immune status of the calves rather than their daily amount of milk offered (Quigley et al., 2006).
Moringa leaves have a very high biological value and considerable potential for adoption as feed for ruminant fodder resource. Moringa leaves are inexpensive, easily available and provides unconventional source of nutrient. Moringa oleifera plants are readily available in Madhya Pradesh. On the basis of the findings of the present experiment, it can be concluded that dry Moring leaf meal can be successfully added to the calf starter (first solid feed offered to the calves) as well as concentrate mixture. Upto 10 per cent replacement of calf starter and concentrate mixture can be done with Moringa oleifera leaf meal which improves the body weight gain, feed intake and protein intake of Murrah buffalo calves. As the Moringa leaf is cheaper and easily available, it can be added to the diet of the Murrah buffalo calves.

\section{References}

Abd El-Aal, A.E., El-Ashry, M.A., Fekry A.E. and Elwan, K.M. (2000). Growth performance, liver and thyroid functions in buffalo calves reared on milk replacers supplemented with hydrogenated oils. Arab Journal of Nuclear Sciences and Applications, 24: 49-60.

Ahmad, A.E., Ibrahim, A.A.S., Ebtehag, I.M.A.E., Mohamed, S.A. and Hassan, M.S. (2017). Effect of feeding dry Moringa oleifera leaves on the performance of suckling buffalo calves. Asian Journal of Animal Science, 11: 32-39.

Ali, S.B., Kawitkar, S.B., Deshmukh, A.D., Dhok. A.P., Jawale, M.R., Chopde, S.V. and Parihar, N.B. (2018). Performance of goats fed Moringa oleifera leaf meal incorporated in concentrate mixture. Indian Journal of Animal Nutrition, 35(2): 239-241.

Anderson, K.L., Nagaraja, T.G., Morrill, J.L., Avery, T.B., Galitzer, S.J. and Boyer, 
J.E. (1987). Ruminal microbial development in conventionally or earlyweaned calves. Journal of Animal Science, 64(4): 1215.

Anjorin, T.S., Ikokoh, P. and Okolo, S. (2010). Mineral composition of Moringa oleifera leaves, pods and seeds from two regions in Abuja, Nigeria. International Journal Agriculture and Biology, 12: 431-434.

Anwar, F., Ashraf, M. and Bhanger. (2015). Interprovenance variation in the composition of Moringa oleifera oil seeds from Pakistan. Journal of the American Oil Chemists Society, 82: 4551.

AOAC (2012). Association of Analytical Chemists. Official Methods of Analysis $19^{\text {th }}$ Edn., Virginia, USA.

Bartlett, K.S., Mckeith, F.K., Vandehaar, M.J., Dhal, G.E. and Drackley, J.K. (2006). Growth and body composition of dairy calves fed milk replacers containing different amounts of protein at two feeding rates. Journal of Animal Science, 84: 1454-1467.

Chimonyo, M., Kusina, N.T., Hamudikuwanda, H. and Nyoni, O. (2000). Reproductive performance and body weight changes in draught cows in a smallholder semi-arid farming area of Zimbabwe.

Tropical Animal Health and Production, 32(6): 405-415.

Deshmukh, P. (2014). Antibacterial and immune modulatory activity of Moringa oleifera in albino rats. M.V.Sc. thesis (Department of Veterinary Pharmacology and Toxicology), Nanaji Deshmukh Veterinary Science University, Jabalpur, M.P. India.

El-Badawi, A.Y., Omer, H.A.A., Abedo, A.A. and Yacout, M.H.M. (2014). Response of growing New Zealand white rabbits to rations supplemented with different levels of Moringa oleifera dry leaves. Global Veterinaria, 12: 573-582.
Fahey, J.W., Zalcmann, A.T and Talalay, P. (2001). The chemical diversity and distribution of glucosinolates and isothiocyanates among plants. Phytochemistry, 56: 5-51.

Farooq, M.K. and Qudoos, A. (1999). Constraints in the adoption of modern livestock practices. Pakistan Veterinary Journal, 19(1): 53-55.

Gakuya, D.W., Mbugua, P.N., Kavoi, B and Kiama, S.G. (2014). Effect of supplementation of Moringa oleifera leaf meal in broiler chicken feed. International Journal of Poultry Science, 13: 201-213.

Iqbal, M. and Ahmad, M. (2002). An assessment of livestock production potential in Pakistan: Implications for livestock sector policy. The Pakistan Development Review, 38(4): 615-628.

Kertz, A.F., Barton, B.A. and Reutzel, L.F. (1998). Relative efficiencies of wither height and body weight increase from birth until first calving in Holstein cattle. Journal of Dairy Science, 81: 1479-1482.

Mahmoud, A.E.M. (2013). Effect of feeding on Moringa oleifera stems on productive performance of growing lambs. Egyptian Journal of Nutrition and Feeds, 16(2): 281-292.

Moran, J.B. (2011). Factors affecting high mortality rates of dairy replacement calves and heifers in the tropics and strategies for their reduction. Asian Australasian Journal of Animal Science, 24(9): 1318-1328.

Oliveira, J.T.A., Silvana, B.S., Ilka, M.V., Benildo, S.C. and Renato, A.M. (1999). Compositional and nutritional attributes of seeds from the multiple purpose tree Moringa oleifera Lamarck. Journal of the Science of Food and Agriculture, 79: 815-820.

Pradhan, B.C. (2016). Valuation of hematological and biochemical 
parameters of goats of central Odisha environment fed on natural grazing land of Odisha. The Pharma Innovation Journal, 5(5): 83-90.

Quigley, J.D., Wolfe, T.A. and Elsasser, T.H. (2006). Effects of additional milk replacer feeding on calf health, growth, and selected blood metabolites in calves. Journal of Dairy Science, 89: 207-216.

Ramachandran, C., Peter K.V. and Gopalakrishnan, P.K. (1980). Drumstick (Moringa oleifera): a multipurpose Indian vegetable. Economic Botany, 34: 276-283.
Saleh, M.S., Bendary M.M. and Elready K.F. (2006). Raising buffalo calves on cow's milk. Journal of Agricultural Research, Tanta University, 32: 794-806.

Sarwatt, S.V., Milangha, M.S., Lekule, F.P. and Madalla, N. (2004). Moringa oleifera and cottonseed cake as supplements for smallholder dairy cows fed Napier grass. Livestock Research for Rural Development, 16(6).

Shakya, A., Roy, B. and Baghel, R.P.S. (2017). Effect of soymilk as partial milk replacer on feed intake and growth performance on Murrah buffalo calves. Buffalo Bulletin, 36(3): 537-546.

\section{How to cite this article:}

Bhavna Aharwal, Biswajit Roy, G.P. Lakhani, R.P.S. Baghel, Kiran Pal Singh Saini and Aayush Yadav. 2018. Effect of Moringa oleifera Leaf Meal on Feed Intake and Growth Performance of Murrah Buffalo Calves. Int.J.Curr.Microbiol.App.Sci. 7(09): 1960-1973. doi: https://doi.org/10.20546/ijcmas.2018.709.238 